\title{
Zinc-Biofortified Rice: A Sustainable Food- Based Product for Fighting Zinc Malnutrition
}

\author{
Mark Ian C. Calayugan, B. P. Mallikarjuna Swamy, Chau Thanh Nha, \\ Alvin D. Palanog, Partha S. Biswas, Gwen Iris Descalsota-Empleo, \\ Yin Myat Myat Min, and Mary Ann Inabangan-Asilo
}

\begin{abstract}
The lack of dietary diversity among poor communities has led to nutritional consequences, particularly zinc deficiency. An adequate intake of mineraland vitamin-rich food is necessary for achieving and maintaining good health. Zinc is one of the micronutrients considered essential to improve human health and decrease the risk of malnutrition. Biofortification of rice through breeding is a costeffective and sustainable strategy to solve micronutrient malnutrition. The Biofortification Priority Index prepared by HarvestPlus clearly identified several countries in Asia with an immediate need for $\mathrm{Zn}$ biofortification. The International Rice Research Institute (IRRI) and its national partners in target countries are making efforts to develop $\mathrm{Zn}$-biofortified rice varieties. The first set of high- $\mathrm{Zn}$ rice varieties has been released for commercial cultivation in Bangladesh, India, the Philippines, and Indonesia. Efforts have begun to mainstream grain $\mathrm{Zn}$ to ensure that the $\mathrm{Zn}$ trait becomes an integral part of future varieties. Huge scope exists to
\end{abstract}

\author{
M. I. C. Calayugan \\ International Rice Research Institute, Metro Manila, Philippines \\ University of the Philippines, Los Baňos, Laguna, Philippines \\ B. P. M. Swamy $(\bowtie) \cdot$ M. A. Inabangan-Asilo \\ International Rice Research Institute, Metro Manila, Philippines \\ e-mail: m.swamy@irri.org \\ C. T. Nha \\ Cuu Long Delta Rice Research Institute, Cần Thơ, Vietnam
}

\author{
A. D. Palanog \\ International Rice Research Institute, Metro Manila, Philippines \\ Philippine Rice Research Institute, Negros Occidental, Philippines \\ P. S. Biswas \\ Bangladesh Rice Research Institute, Gazipur, Bangladesh \\ G. I. Descalsota-Empleo \\ University of Southern Mindanao, North Cotabato, Philippines \\ Y. M. M. Min \\ Department of Agricultural Research, Yezin, Myanmar
}


apply advanced genomics technologies such as genomic selection and genome editing to speed up high-Zn varietal development. An efficient rice value chain for $\mathrm{Zn}$-biofortified varieties, quality control, and promotion are essential for successful adoption and consumption. The development of next-generation high- $\mathrm{Zn}$ rice varieties with higher grain-Zn content, stacking of multiple nutrients, along with good grain quality and acceptable agronomic traits has to be fast-tracked. Healthier rice has a large demand from all stakeholders, so we need to keep up the pace of developing nutritious rice to meet the demand and to achieve nutritional security.

Keywords Rice $\cdot$ Malnutrition · Biofortification · Zinc $\cdot$ QTL $\cdot$ Gene $\cdot$ Bayesian analysis

\section{Introduction}

The human body needs micronutrients for proper growth and development and to maintain good health (Maret 2017; Palanog et al. 2019). However, deficiencies in these elements and associated health risks are commonly reported in all age groups, especially in preschool children, women, and elderly people in the developing world (Caulfield et al. 2006). An estimated one-third of the global population suffers from micronutrient malnutrition, mainly because of the large dependence on cereal staples for daily nutritional needs without access to a diversified diet and supplementation (Ritchie et al. 2018). The urgent need to address micronutrient malnutrition has been widely recognized globally; hence, decreasing childhood mortality and maternal death by eradicating malnutrition is an important Sustainable Development Goal (Hanieh et al. 2020).

Among the micronutrients, zinc ( $\mathrm{Zn}$ ) is most essential for vital organs, enzymatic activity, tissue growth and development, cognitive function, immunity, etc. There is therefore a need for a regular daily supply of $\mathrm{Zn}$ in the required quantity to have healthy and productive populations (Prasad et al. 2014; Chasapis et al. 2020). However, an estimated two billion people suffer from $\mathrm{Zn}$ deficiency-related health consequences and most of them are resource-poor urban and rural dwellers (Rampa et al. 2020). The disability-adjusted life years (DALYs) due to $\mathrm{Zn}$ malnutrition strongly impact annual GDP growth, and hamper economic development in the developing world (Gödecke et al. 2018). Multiple interventions such as fortification of foods, micronutrient supplementation, and food diversification have been employed to mitigate $\mathrm{Zn}$ malnutrition; however, recurring costs and poor accessibility and awareness among the rural masses have resulted in limited success (Bouis 2017). Increasing the mineral density in the edible part of the major staple crops, which is also popularly called "biofortification," has been proven to be effective in alleviating malnutrition without much additional cost. This complementary foodbased approach is the safest and cheapest way to deliver nutrients on a larger scale to the target populations (Bouis and Saltzman 2017). 
Rice is among the target staple food crops for $\mathrm{Zn}$ biofortification in different countries of South Asia, Southeast Asia, and Africa (Siwela et al. 2020). The Biofortification Priority Index prepared by HarvestPlus clearly identified several countries in Asia with an immediate need for Zn biofortification (HarvestPlus 2020). The International Rice Research Institute (IRRI) and its national partners in target countries are making efforts to develop $\mathrm{Zn}$-biofortified rice varieties. The first set of high- $\mathrm{Zn}$ rice varieties has been released for commercial cultivation in Bangladesh, India, the Philippines, and Indonesia (Inabangan-Asilo et al. 2019). Efforts are in place to mainstream the breeding of high- $\mathrm{Zn}$ rice by applying advanced breeding techniques and genomic tools to make sure $\mathrm{Zn}$ will be an essential component of all future varietal releases from the main breeding pipelines of IRRI (CGIAR 2018).

Over the past decade, great progress has been made in our understanding of $\mathrm{Zn}$ homeostasis in rice from a biofortification perspective and in the development of high- $\mathrm{Zn}$ rice. In this chapter, we would like to provide some insights into the recent advances in developing $\mathrm{Zn}$-biofortified rice for the target countries.

\section{Zn Is Critical for Human Health}

Zinc plays an important role in the catalytic function of most of the enzymes needed for the structural stability and functioning of more than 3000 proteins, helps to maintain membrane stability, and protects tissues and cells from oxidative damage (Cakmak 2000; Broadley et al. 2007; Andreini et al. 2009; Maret and Li 2009).

Zinc deficiency is one of the major causes of child mortality worldwide (Black et al. 2008), which has been estimated to affect more than 178 countries (WHO 2003). Zn-deficient children are highly prone to diarrhea, respiratory ailments, poor cognitive function, and stunting (Brooks et al. 2004; Sazawal et al. 2007; Tielsch et al. 2007; Young et al. 2014). Zn deficiency during the first 1000 days for children after birth causes irreversible damage leading to less chance of survival, poor immune system and cognitive ability, and stunting (UNICEF 2013). Hence, a regular daily supply of $\mathrm{Zn}$ is highly essential, but this is rarely achieved by most resource-poor people. Thus, adequate $\mathrm{Zn}$ nutrition is essential for good health, especially for children and pregnant women for growth and development (IZiNCG 2009). The daily Zn requirement of individuals varies from 9 to $11 \mathrm{ppm}$ depending on age, gender, and health conditions, but preschool children and pregnant and lactating women need more Zn (IOM 2001; Welch and Graham 2004; Iqbal et al. 2020; Alqabbani and AlBadr 2020).

\section{Rice Biofortification with High Grain Zn}

Rice is the single most important source of energy and nutrition for more than half of the world's population (Gross and Zhao 2014). It is a major staple crop in more than 40 countries and supplies at least $20 \%$ of the daily caloric intake of more than 
3.5 billion people (FAO 2014). Asia, with $60 \%$ of the global population, consumes more than $90 \%$ of the total rice produced annually (Milovanovic and Smutka 2017). Annual per capita rice consumption exceeds $100 \mathrm{~kg}$ in some Asian countries (FAO 2016). However, milled rice is less nutritious; thus, most of the poor people who largely depend on rice without access to a mineral-rich diverse diet suffer from hidden hunger, including $\mathrm{Zn}$ deficiency.

Food-based solutions were found to be safe and effective in controlling and preventing micronutrient deficiencies, especially when multiple deficiencies occur (Torheim et al. 2010; Szymlek-Gay et al. 2009). Several studies reported that the consumption of a diverse diet and crops enriched with mineral elements provides more nutrition (Brown et al. 2002; WHO 1998). Recently, biofortification of staple crops has become a popular method for tackling malnutrition. It is the process of increasing the density of readily bioavailable mineral elements by breeding or biotechnological approaches (Garg et al. 2018) for staple food crops such as rice, which has been obtaining increased attention by breeders and policymakers in recent times. Biofortification has the lowest per capita costs vis-à-vis other interventions, and it is especially easily accessible and affordable for rural populations (Ma et al. 2008). Therefore, increasing grain-Zn content would create a significant impact on human health. One estimate suggested that an additional $8 \mu \mathrm{g} / \mathrm{g}$ of $\mathrm{Zn}$ in raw milled rice over the baseline $\mathrm{Zn}(16 \mu \mathrm{g} / \mathrm{g})$ in cultivated varieties could help to reach the amount equivalent to $30 \%$ of the Estimated Average Requirement per day (HarvestPlus 2012).

\section{Trait Development for High Grain Zn}

\subsection{High-Zn Donor Identification}

Rice is endowed with abundant genetic diversity and thereby provides needed genetic variability for rice breeding programs (Rana and Bhat 2004). More than 230,000 rice accessions are maintained in global gene banks, which include landraces, cultivars, varieties, and aromatic and wild rice (Li et al. 2014). Among the different species or subgroups, wild rice, landraces, and aus accessions were found to be a rich source of micronutrients; they have several-fold higher nutrients than cultivated rice (Cheng et al. 2005; Banerjee et al. 2010; Descalsota-Empleo et al. 2019 a, b). Aus accessions are genetically closer to popularly grown indica rice varieties, so they can be readily used by breeding programs to improve the $\mathrm{Zn}$ content of modern rice varieties. Some aus accessions such as Kaliboro, Jamir, UCP122, DZ193, and Khao ToT Long 227 have higher content of grain Zn (Norton et al. 2014; Descalsota et al. 2018). We are efficiently using aus germplasm in our breeding programs at IRRI and have also widely shared these donor lines with our partners for use in their breeding programs. The accessions of the $3 \mathrm{~K}$ Genome Project, Multi-parent Advanced Generation Inter-Cross (MAGIC)-derived lines and wild 
rice introgression lines, were also characterized to identify valuable donors for grain $\mathrm{Zn}$ and used in genetic dissection studies (Bandillo et al. 2013; Swamy et al. 2018a; Descalsota et al. 2018; Zaw et al. 2019). Moreover, large scope exists for revisiting gene banks to screen for high grain $\mathrm{Zn}$ and other beneficial elements using advanced high-throughput phenotyping technologies. Similarly, a systematic effort to collect and characterize heirloom rice for nutritional value in partner countries will help in breeding for improved nutrition.

\subsection{Association Between Yield and Zn}

The development of high-yielding Zn-biofortified rice with a combination of desirable agronomic traits and tolerance of pests and diseases is a must for their successful adoption and consumption. Both yield and grain $\mathrm{Zn}$ are genetically complex traits and are hugely influenced by external environmental factors (Zaw et al. 2019; Descalsota-Empleo et al. 2019a). In most cases, a negative association was reported between grain-Zn content and yield, and in a few specific germplasm accessions and populations a nonsignificant negative relationship or no relationship was reported (Gregorio 2002; Norton et al. 2010; Morete et al. 2011; Anandan et al. 2011; Nha 2019). Under different soil Zn conditions and in a set of different aromatic accessions and landraces, a positive relationship between grain $\mathrm{Zn}$ and yield was reported (Wissuwa et al. 2008; Gangashetty et al. 2013; Sathisha 2013). Therefore, for the identification of stable high-Zn donor lines with higher or more acceptable yield, the use of appropriate breeding methods and selection strategies is needed to successfully combine yield and grain $\mathrm{Zn}$.

\subsection{Molecular Dissection of Grain Zn}

\subsubsection{QTLs and Meta-QTLs Associated with Grain Zn}

Zn uptake, transport, and accumulation in the grain are governed by a complex network of quantitative trait loci (QTLs) and genes. A comprehensive review of QTLs identified for grain $\mathrm{Zn}$ was carried out and detailed discussion presented by Swamy et al. (2016). Several QTLs with moderate to high phenotypic variance were reported for grain $\mathrm{Zn}$ on all 12 chromosomes of rice. At IRRI, our group has also carried out several QTL mapping studies using biparental and multiparental populations and germplasm collections (Table 1). Swamy et al. (2018a) reported eight QTLs for grain-Zn content. All of these QTLs were distributed across the rice genome, having the lowest frequency (one QTL) on chromosomes 1, 9, and 11 and the highest frequency (seven QTLs) on chromosome 12. Chromosome 7 had the second highest number (six) of QTLs. However, the QTLs on chromosomes 7 and 12 were consistent over different backgrounds and environments. The QTLs detected on 
Table 1 QTLs identified for grain-Zn content in rice

\begin{tabular}{|c|c|c|c|c|}
\hline QTL & $\mathrm{LOD} / p$ value & $\begin{array}{l}\text { PVE } \\
(\%)\end{array}$ & $\begin{array}{l}\text { Additive } \\
\text { effect }(\mathrm{mg} / \\
\mathrm{kg})\end{array}$ & Reference \\
\hline $\begin{array}{l}q Z n_{1.1}, q Z n_{2.1}, q Z n_{3.1}, q Z n_{3.2}, q Z n_{5.1}, \\
q Z n_{6.1}, q Z n_{8.1}, q Z n_{8.2}, q Z n_{9.1}, q Z n_{10.1}, \\
q Z n_{12.1}\end{array}$ & $2.5-12.4$ & $\begin{array}{l}3.0- \\
36.0\end{array}$ & $0.21-6.60$ & $\begin{array}{l}\text { Swamy et al. } \\
(2018 a)\end{array}$ \\
\hline $\begin{array}{l}q Z n_{2.1}, q Z n_{2.2}, q Z n_{3.1}, q Z n_{6.1}, q Z n_{6.2} \\
q Z n_{8.1}, q Z n_{11.1}, q Z n_{12.1}, q Z n_{12.2}\end{array}$ & $4.3-10.3$ & $\begin{array}{l}7.5- \\
22.8\end{array}$ & $0.9-2.1$ & $\begin{array}{l}\text { Swamy et al. } \\
(2018 \text { b) }\end{array}$ \\
\hline $\begin{array}{l}q Z n_{1.1}, q Z n_{2.1}, q Z n_{4.1}, q Z n_{6.1}, q Z n_{6.2} \\
q Z n_{7.1}, q Z n_{12.1}\end{array}$ & $0.001-0.0001$ & $\begin{array}{l}9.2- \\
13.75 \\
\end{array}$ & - & $\begin{array}{l}\text { Descalsota et al. } \\
(2018)\end{array}$ \\
\hline$q Z n_{1.1}, q Z n_{6.1}, q Z n_{12.1}, q Z n_{12.2}, q Z n_{12.3}$ & $\begin{array}{l}0.0000905- \\
0.00029\end{array}$ & $\begin{array}{l}11.9- \\
17.9\end{array}$ & - & $\begin{array}{l}\text { Descalsota- } \\
\text { Empleo et al. } \\
(2019 a)\end{array}$ \\
\hline $\begin{array}{l}q Z n_{2.1}, q Z n_{3.1}, q Z n_{5.1}, q Z n_{5.2}, q Z n_{7.1} \\
q Z n_{8.1}, Z n_{9.1}, q Z n_{11.1}\end{array}$ & $2.77-8.99$ & $\begin{array}{l}8.6- \\
27.7\end{array}$ & $0.81-2.06$ & $\begin{array}{l}\text { Descalsota- } \\
\text { Empleo et al. } \\
(2019 b)\end{array}$ \\
\hline$q Z n_{1.1}, q Z n_{6.1}, q Z n_{6.2}$ & $2.6-3.9$ & $\begin{array}{l}2.9- \\
34.2\end{array}$ & $0.06-3.2$ & $\begin{array}{l}\text { Dixit et al. } \\
(2019)\end{array}$ \\
\hline$q Z n_{1}, q Z n_{5}, q Z n_{7}$ & - & $\begin{array}{l}17.57- \\
20.0\end{array}$ & - & Zaw et al. (2019) \\
\hline$q Z n_{1.1}, q Z n_{5.1}, q Z n_{9.1}, q Z n_{12.1}$ & $3.14-5.2$ & $\begin{array}{l}8.96- \\
15.26 \\
\end{array}$ & $0.77-0.96$ & $\begin{array}{l}\text { Calayugan et al. } \\
(2020)\end{array}$ \\
\hline $\begin{array}{l}Z_{n_{1.1}}, q Z n_{1.2}, q Z n_{1.3}, Z n_{2.1}, q Z n_{4.1} \\
q Z n_{5.1}, Z n_{6.1}, q Z n_{7.1}, q Z n_{9.1}, Z n_{10.1} \\
q Z n_{11.1}, q Z n_{11.2}, Z n_{11.3}, q Z n_{12.1}\end{array}$ & $3.28-15.36$ & $\begin{array}{l}12.60- \\
46.80\end{array}$ & $2.62-4.73$ & $\begin{array}{l}\text { Jeong et al. } \\
(2020)\end{array}$ \\
\hline$q Z n_{3.1}, q Z n_{3.1}, q Z n_{4.2}$ & $4.11-9.16$ & $\begin{array}{l}9.89- \\
24.56\end{array}$ & $0.0001-0.1$ & Lee et al. (2020) \\
\hline
\end{tabular}

$P V E$ phenotypic variance explained

chromosome 7 contributed 5.3-35.0\% of the phenotypic variance for grain- $\mathrm{Zn}$ content in different backgrounds, while the QTLs on chromosome 12 contributed 9-36\% (Swamy et al. 2016, 2018a). In another study, Swamy et al. (2018b) detected nine QTLs responsible for Zn on chromosomes 2, 3, 6, 8, 11, and 12 through two doubled-haploid (DH) populations derived from crosses of PSBRc $82 \times$ Joryeongbyeo and PSBRc82 $\times$ IR69428. Recently, association mapping experiments using diversity panels for grain Zn led to the identification of seven QTLs on chromosomes 1, 2, 4, 6, 7, and 12 by Descalsota et al. (2018) and three QTLs on chromosomes 1, 5, and 7 by Zaw et al. (2019). All of these findings show that numerous QTLs for Zn highlight the genetic complexity of this trait.

Meta-QTL analysis provides consolidated, precise, and smaller confidence intervals for multiple QTLs reported for a trait (Goffinet and Gerber 2000; Arcade et al. 2004; Swamy et al. 2011). Jin et al. (2015) identified 22 meta-QTLs on ten different chromosomes for grain-Zn content (rMQTLs). Similarly, Raza et al. (2019) carried out meta-QTL analysis of grain-Zn QTLs reported from 24 mapping populations 
and three diverse germplasm sets and identified 46 MQTLs. Seven meta-QTLs $\left(r M Q T L_{2.1}, r M Q T L_{4.4}, r M Q T L_{6.4}, r M Q T L_{8.2}, r M Q T L_{8.3}, r M Q T L_{8.4}\right.$, and $\left.r M Q T L_{12.4}\right)$ were found to be common between two studies (Jin et al. 2015; Raza et al. 2019). In another study, 208 QTLs for grain $\mathrm{Zn}$ from 26 studies were projected on the consensus map and eventually 45 meta-QTLs were identified (Soe 2020). Overall, the confidence intervals of all the MQTLs were narrower vis-à-vis the mean values of the original QTLs. Several consistent QTLs and associated markers were identified, which are useful for efficient marker-assisted selection (MAS) programs. In addition, precise meta-QTL regions provide an opportunity to shortlist candidate genes for further functional validation.

\subsubsection{Network of Metal Homeostasis Genes}

Mapping of major-effect QTLs/genes for grain $\mathrm{Zn}$ and understanding their molecular basis can fast-track the development of Zn-biofortified rice through MAS. The genomic regions of important QTLs associated with grain Zn identified in numerous studies contained multiple hypotheticals and functionally annotated genes that function as metal chelators and ion transporters. A list of important genes associated with $\mathrm{Zn}$ homeostasis in rice is summarized in Swamy et al. (2016). Rice roots produce chemicals that free up mineral elements from the soil complex and promote their root uptake from the soil (Widodo et al. 2010; Nozoye et al. 2011). Several genes/gene families are involved in biosynthesis of phytosiderophores, mineral uptake, transport, and loading such as OsDMAS, OSSAMS, OSNAS, OSTOM1, and OSNAAT (Inoue et al. 2003, 2008; Bashir et al. 2006; Johnson et al. 2011). Zinc finger transcription factors such as OsZIPI, OsZIP3, OsZIP4, OsZIP5, and OsZIP9 are major $\mathrm{Zn}$ transporters within the rice plant (Ramesh et al. 2003; Ishimaru et al. 2005; Lee et al. 2010a, b). In separate studies conducted using connected populations, ZIP family genes such as OsZIP5 and $O S Z I P 9$ were identified along with another 140 candidate genes (Nha 2019). In a study using DH populations, OsZIP6 was identified as a primary candidate gene associated with grain Zn (Calayugan et al. 2020). Similarly, OsVIT and OsYSL family genes are involved in $\mathrm{Zn}$ transport across the tonoplast and phloem, respectively (Sasaki et al. 2011; Kakei et al. 2012; Zhang et al. 2012; Lan et al. 2013).

The well-characterized $\mathrm{Zn}$ metal homeostasis genes can be manipulated through genetic engineering to improve grain-Zn content in rice (Trijatmiko et al. 2016). The advanced genome editing techniques using zinc-finger nucleases (ZFNs), transcription activator-like effector nucleases (TALENs), and clustered regularly interspaced short palindromic repeats (CRISPR)/Cas systems can be used to induce modifications at specific genomic loci (Kim et al. 1996; Christian et al. 2010; Jinek et al. 2012; Chen and Gao 2013; Gao 2015). The Zn homeostasis genes can be major target sites for genome editing to improve grain$\mathrm{Zn}$ content in rice. 


\subsubsection{Bayesian Network Analysis of Grain Yield and Zn}

A Bayesian genomic prediction network $(\mathrm{BN})$ provides valuable information on interactions between multiple traits and SNP markers and helps to establish relationships among them. It clearly depicts the strength and direction of associations among traits and SNP markers. In a way, it helps to validate the QTLs, genes, or trait associations identified by genome-wide association analysis (Zaw et al. 2019). In a MAGIC Plus population, a BN was used among Zn- and yield-related traits. The results clearly showed a complex relationship among traits (Fig. 1). Among the agronomic traits studied for their relationship with grain $\mathrm{Fe}$ and $\mathrm{Zn}$, only panicle length had a direct effect on Fe and $\mathrm{Zn}$ content in rice (Descalsota et al. 2018). Zaw et al. (2019) conducted BN analysis in a global MAGIC population using 8110 SNP markers and 16 traits, including grain $\mathrm{Zn}$. At a BN strength of more than 0.5, strong direct associations were reported among traits such as yield $\rightarrow$ zinc, zinc $\rightarrow$ filled grains, iron $\rightarrow$ zinc, and iron $\rightarrow$ grain length. Zn was associated with eight markers for each of the traits. In general, Fe and $\mathrm{Zn}$ content have strong positive correlations, thus providing huge opportunities to improve both minerals together. It is interesting that in both $\mathrm{BN}$ studies there was no direct effect of yield on $\mathrm{Zn}$, indicating that combining high yield potential and high grain-Zn content is possible in order to develop successful Zn-biofortified rice varieties. We emphasize that there is a need to thoroughly dissect the influence of panicle length on grain $\mathrm{Zn}$. It is commonly observed that increased yield dilutes $\mathrm{Zn}$ content, which results in negative correlations between these traits. There is therefore a need to make adjustments for grainZn mapping studies (McDonald et al. 2008).

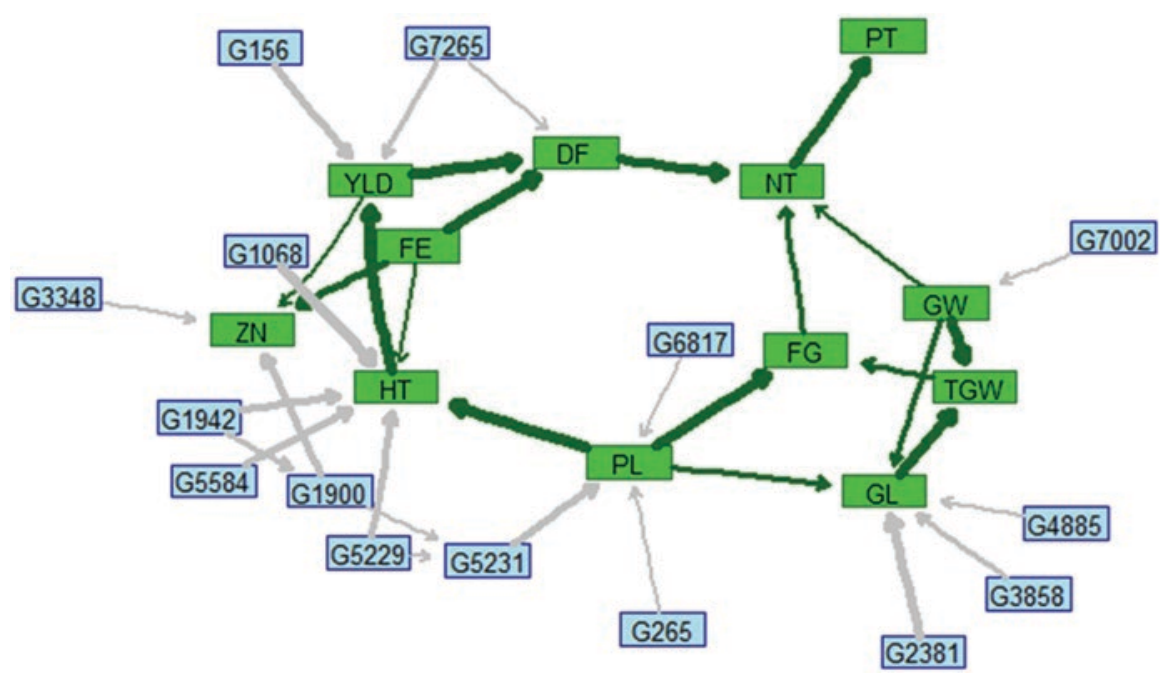

Fig. 1 Bayesian network analysis of grain $\mathrm{Zn}$ and agronomic traits. Note: $\mathrm{Zn}$ zinc, $F e$ iron, $H T$ plant height, $D F$ days to flowering, $N T$ number of tillers, $P T$ productive tillers, $G L$ grain length, $G W$ grain width, $T G W$ thousand-grain weight, $Y L D$ grain yield 


\subsection{Multi-Trait Genomic Selection for Zn Biofortification}

QTL mapping and GWAS methods are routinely used for molecular dissection of complex traits; however, they have limited power in detecting minor-effect loci (Bernardo 2008; Collard and Mackill 2008; Ben-Ari and Lavi 2012). In contrast, genomic selection (GS) considers genome-wide effects, including both major and minor loci, and thereby assesses the genomic estimated breeding values (GEBVs) of breeding lines (Meuwissen et al. 2001). With the recent advances in statistics, deep machine learning models are helpful in accurately estimating GEBVs and their cross-validation in training or reference sets (Montesinos-López et al. 2019). Since GS captures total genetic variance, it addresses the existing limitations of GWAS and QTL mapping to improve traits (de los Campos et al. 2009). In addition, it speeds up selection cycles, which enhances annual genetic gain and saves cost significantly (Shamshad and Sharma 2018). Therefore, great opportunity exists for employing GS-related strategies that capture both major- and minor-effect alleles to increase the genetic gain for grain yield and grain-Zn content in rice.

Selection for higher yield and other desirable agronomic traits along with high grain-Zn content is an integral part of Zn biofortification; however, both yield and $\mathrm{Zn}$ are genetically complex and difficult to manipulate or simultaneously improve (Garcia-Oliveira et al. 2018; Zaw et al. 2019). The rate of genetic gain for grain yield becomes stagnant at $\sim 1 \%$ yearly. This is not sufficient to meet future demand for rice, not to mention the strong impacts of complex genetic architecture and genotype-environment interactions (Peng et al. 2000, 2004; Wassmann et al. 2009). The combined genetic gain for yield and $\mathrm{Zn}$ will be relatively inferior when compared with that for individual traits. Therefore, implementing multi-trait-based population improvement through genomic selection is an efficient approach.

In rice, Spindel et al. (2015) reported prediction accuracies of single-trait genomic selection (ST-GS) models for grain yield at 0.31, while Arbelaez et al. (2019) have shown predictive accuracies for grain yield at 0.36 . Meanwhile, multi-trait genomic selection (MT-GS) models have illustrated higher predictive abilities than ST-GS models and the results are obvious, especially when low-heritability traits are paired with a genetically correlated secondary trait with higher heritability (Jia and Jannink 2012; Hayashi and Iwata 2013; Guo et al. 2014; Schulthess et al. 2016). Many findings have used MT-GS approaches in crop breeding, but not yet in rice. Schulthess et al. (2016) have confirmed the predictive ability of MT-GS in outperforming ST-GS pipelines for grain yield and protein content in rye. Lado et al. (2018) have verified combining two, three, and four traits in bread wheat in exploiting the benefits of MT-GS under different cross-validation scenarios. The use of correlated traits in MT-GS models gives the best prediction accuracies in a two-trait scenario. GS in maize showed higher prediction accuracy in DH populations than a GWAS panel using the same set of GBS and rAmpSeq markers, and GS outperformed MAS in predicting the performance of $\mathrm{Zn}$ content in maize (Guo et al. 2020). Although most of the available GS methods increased predictive ability, Zn breeders should target multiple independent phenotypes from multi-environments. Thus, multi-trait and 
multi-environment (MTME) models have been established to employ the information on multiple traits evaluated in multiple environments, which improves predictive ability compared to conventional, pedigree, and independent GS analysis (Montesinos-Lopez et al. 2016).

\section{Development of High-Zn Rice}

\subsection{Phenotyping of Grain Zn}

To enhance selection accuracy and to significantly improve a breeding program, reliable phenotyping is crucial. Accurate phenotyping for any trait involves a standard protocol with a set of specific standards. Usually in large biofortification breeding programs like the one at IRRI, we handle a huge number of breeding lines every season, so there is a need for quick turnover of materials with accurate phenotyping for grain Zn. Efficient high-throughput dehulling, milling, and Zn measurement protocols and equipment are needed for successful $\mathrm{Zn}$ biofortification of rice (Fig. 2) (Swamy et al. 2016; Guild et al. 2017). Several low-throughput qualitative, semiquantitative, and quantitative methods are available for the estimation of grain-Zn content in rice and other cereals. Inductively coupled plasma optical emission spectrometry (ICP-OES) is used to assess nutrient density in grains (Zarcinas et al. 1987); this method is more accurate but low-throughput and input-intensive and it requires trained staff. X-ray fluorescence (XRF) is a rapid non-chemical-based

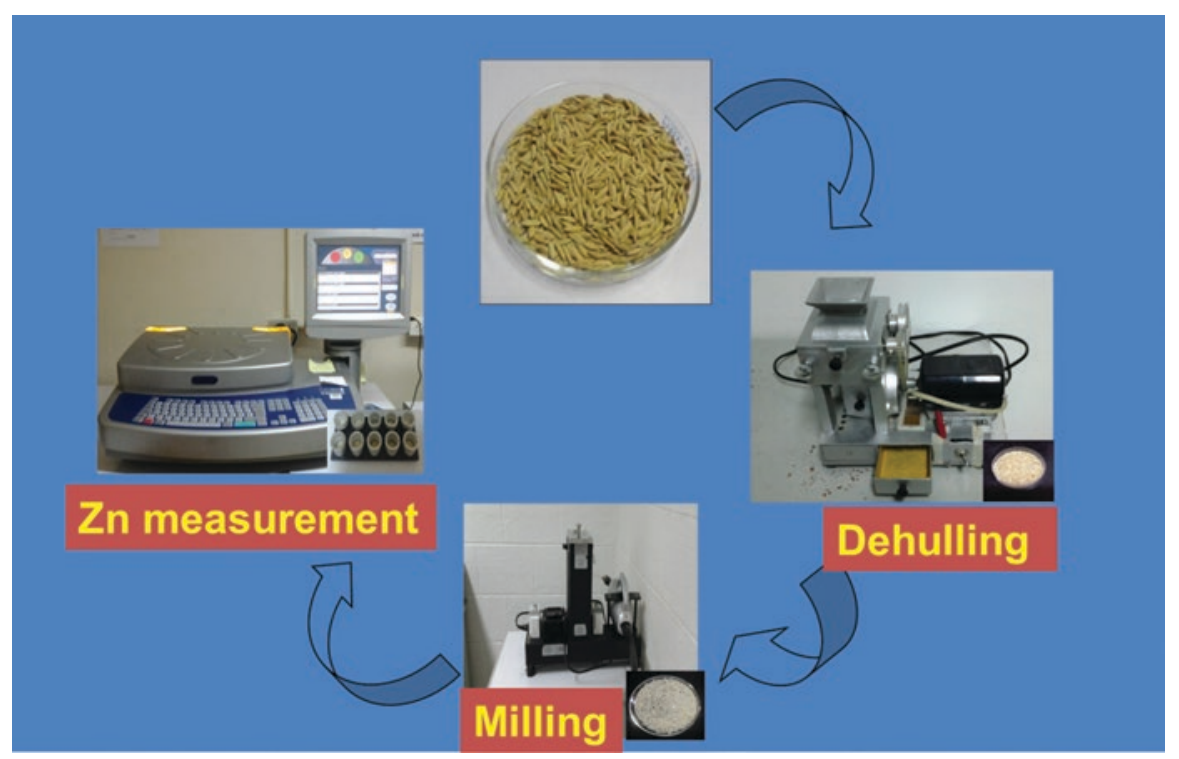

Fig. 2 Phenotyping for grain-Zn milled rice 
method to measure grain- $\mathrm{Zn}$ content in milled rice, which has decreased cost per unit and simultaneously increased selection intensity although it still requires grain processing under a contamination-free environment of exogenous $\mathrm{Zn}$ sources.

\subsection{Setting a Zn Target for Rice Biofortification}

The development of nutritional targets for crops for biofortification breeding was established by a group of experts taking into account the food habits of the target populations, nutrient losses during food processing, and nutrient bioavailability (Hotz and McClafferty 2007). The breeding target was designed to meet the specific nutrient requirement of the target populations considering the baseline micronutrients existing in popular rice varieties and extra micronutrient content to be added to the crop of interest. Zn-biofortified rice is expected to provide $>40 \%$ of the Estimated Average Requirement, which is enough to help overcome Zn-deficiency-induced health risks (Bouis and Saltzman 2017). There is a plan to release high- $\mathrm{Zn}$ rice varieties in three phases: the first set of varieties will have an additional $\mathrm{Zn}$ content of 6-8 ppm, the second wave of varieties will have 8-12 ppm, while the third wave of high-Zn rice varieties will have $12 \mathrm{ppm}$ of additional grain $\mathrm{Zn}$ (Fig. 3).

\subsection{Germplasm Enhancement and Pre-breeding for Grain Zn}

Exploitable genetic variability for any trait, its systematic characterization, and efficient use are essential for a successful breeding program. Most elite modern rice varieties and their closest elite genetic pool have low grain-Zn content (Gregorio 2002). Oryza nivara, O. rufipogon, O. longistaminata, and O. barthii accessions, landraces, colored rice, and aus and aromatic accessions were found to have rich grain-Zn content (Swamy et al. 2016, 2018a, b; Ishikawa et al. 2017). But these accessions may not be agronomically desirable because of their poor phenotype and lower yield. Therefore, a systematic pre-breeding for grain $\mathrm{Zn}$ is essential to develop high- $\mathrm{Zn}$ rice varieties.

The advanced backcross method for genetic dissection of wild rice, and for developing high- $\mathrm{Zn}$ introgression lines, is an attractive approach for efficient use of wild rice accessions (Balakrishnan et al. 2020). Several wild rice-derived introgression lines with high grain $\mathrm{Zn}$ and yield have already been developed by several groups (Ishikawa et al. 2017; Swamy et al. 2018a). Multi-parent-derived populations to select transgressive variants with a combination of desirable traits have yielded many desirable transgressive variants for grain $\mathrm{Zn}$ (Gande et al. 2013; Ishikawa et al. 2017; Descalsota-Empleo et al. 2019a, b). Marker-assisted QTL deployment, QTL pyramiding, and marker-assisted recurrent selection are helpful in germplasm enhancement for grain $\mathrm{Zn}$ with other traits (Hill et al. 2008; Boyle et al. 2017). 


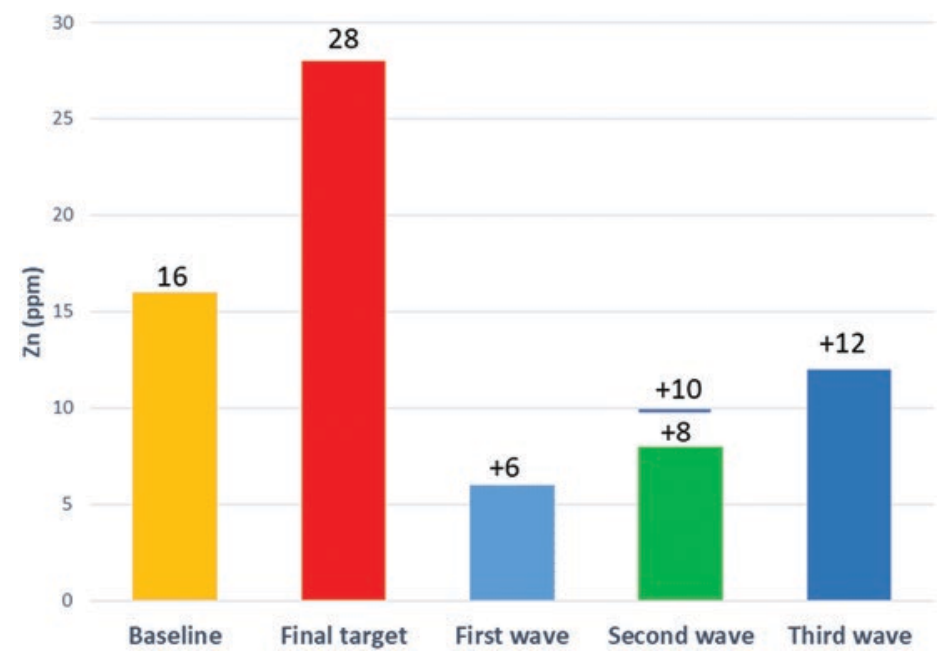

Fig. $3 \mathrm{Zn}$ target set for breeding $\mathrm{Zn}$-biofortified rice varieties

Several studies have characterized germplasm and advanced breeding lines for grain-Zn content (Gregorio et al. 2000; Brar et al. 2011). Garcia-Oliveira et al. (2009) identified 85 introgression lines with the highest quantities of $\mathrm{Zn}$ with a mean value of $27.1 \mathrm{ppm}$. Martínez et al. (2010) phenotyped grain-Zn content in 11,400 rice samples in both brown rice and milled rice and reported corresponding $\mathrm{Zn}$ values of 20-25 ppm and 16-17 ppm, respectively. Gande et al. (2013) identified eight transgressive lines for high $\mathrm{Zn}$ content (31.2-35.5 ppm). Some of these introgression lines, transgressive segregants, and breeding lines can be used as donor lines for $\mathrm{Zn}$ biofortification and even some can be directly tested and released as high-Zn rice varieties for commercial cultivation.

\subsection{Mainstreaming of Zn Biofortification}

Zinc-biofortified rice varieties have been successfully released for cultivation by farmers in some of the target countries. However, developing, releasing, and disseminating a few varieties may not create sustainable and wide-scale impact on human health. At IRRI, mainstream breeding programs are shifting from a siloed trait-based breeding approach to a modernized product development pipeline that effectively integrates the improvement of all traits necessary for market acceptance into a single variety replacement strategy. This new strategy involves using population improvement as a mechanism to drive genetic gain for complex traits, while simultaneously increasing the frequency of trait-favorable alleles. Essential to this strategy is the data-driven identification of a core set of elite lines that 
represent the pool of possible parental lines that can be used in the breeding process (Cobb et al. 2019). Through successive cycles of recurrent selection, mainstream breeding efforts are now able to drive genetic gain and improve the average value of all traits from a product profile in the entire elite gene pool simultaneously (Collard et al. 2017). By integrating selection for high grain-Zn content directly into the mainstream breeding effort, the mean value of grain $\mathrm{Zn}$ among the elite breeding lines will eventually be at or above the recommended allowance of $28 \mathrm{ppm}$ in milled grains. Once this occurs, all the most recently developed new varieties released from the mainstream breeding program will have acceptable concentrations of $\mathrm{Zn}$ in addition to other traits more valued in the marketplace. With minimal effort, maintenance breeding for $\mathrm{Zn}$ can be conducted in elite breeding programs once acceptable grain- $Z n$ content is achieved in order to ensure constant delivery of sufficient $\mathrm{Zn}$ to the diets of nutrition-vulnerable rice-consuming populations. Incumbent upon this strategy is the need for sufficient variation to drive genetic gain for complex traits. A three-phased approach is suggested: elite germplasm characterization, elite germplasm enhancement and selection, and mainstream breeding.

\section{High-Zn Rice Testing and Release}

\subsection{Genotype $\times$ Environment Effects on Grain $\mathrm{Zn}$}

Grain- $\mathrm{Zn}$ content is a complex trait found to be significantly influenced by external soil and climatic factors (Chandel et al. 2010; Anuradha et al. 2012; Swamy et al. 2016; Naik et al. 2020). Meteorological factors such as temperature, relative humidity, and rainfall; soil factors such as organic matter, $\mathrm{pH}$, and nutrient status; and agronomic practices such as fertilizer application, tilling, cultivation system, and irrigation (White and Broadley 2009; Joshi et al. 2010; Chandel et al. 2010) need to be taken into account. Grain-Zn content in a study conducted by Wissuwa et al. (2008) was found to be greatly influenced by the native $\mathrm{Zn}$ in soils, genotype, and $\mathrm{Zn}$ fertilizer application. In a separate study by Wang et al. (2014), water management with alternate wetting and drying (AWD) together with $\mathrm{ZnSO}_{4}$ fertilization showed a positive response for higher yield coupled with higher grain-Zn content in rice. Pandian et al. (2011) conducted field experiments across three locations involving 17 genotypes of rice. The results showed that grain-Zn content varied significantly among the genotypes and locations.

Thus, $\mathrm{G} \times \mathrm{E}$ testing is needed to evaluate promising germplasm and the stability of mineral accumulation across generations and at multiple test sites (Gregorio 2002; Wissuwa et al. 2008; Impa et al. 2013; Naik et al. 2020). Hence, the stability of Zn-biofortified genotypes for grain-Zn content in addition to grain yield is essential for commercial release as varieties. 


\subsection{Zn-Biofortified Rice Varieties Released in Different Countries}

Breeding efforts to biofortify rice with high grain $\mathrm{Zn}$ have resulted in the successful release of several high-Zn rice varieties in several countries of Asia. Five high-Zn rice varieties (BRRI dhan62, BRRI dhan64, BRRI dhan72, BRRI dhan74, and BRRI dhan84) have been released for cultivation in Bangladesh. In India, two high-Zn rice varieties (DRR Dhan45 and Chhattisgarh Zinc Rice-1) are available for farmers and consumers. Similarly, NSIC Rc 460 and Inapari Nutri Zn have been released for farmers' cultivation in the Philippines and Indonesia, respectively. All these high-Zn rice varieties have higher grain-Zn content along with desirable agronomic traits and tolerance of biotic and abiotic stresses (Swamy et al. 2016; Tsakirpaloglou et al. 2019). Several promising high-Zn lines have been successfully tested in Myanmar and Cambodia and in some African countries. We are also making efforts to develop the next wave of Zn-biofortified rice varieties with higher grain-Zn content.

\subsection{High-Zn Rice Traceability and Product Control}

Grain-Zn content in rice is an invisible nutritional trait and no morphological indicators differentiate $\mathrm{Zn}$-biofortified rice from market rice. Maintaining the product integrity of high- $\mathrm{Zn}$ rice throughout the value chain is an important component of successful $\mathrm{Zn}$ biofortification programs. Close monitoring, supervision, and quality control are necessary with proper certification, labeling, branding, and tracing of the product (www. fao.org/tempref/codex/Meetings/CCNFSDU/ccnfsdu36/nf36_11e.pdf). The development of $\mathrm{Zn}$ product-specific molecular marker-based fingerprints and rapid qualitative biochemical marker kits will also help in tracing Zn-rich rice. Blockchain technology is being used in the large-scale dissemination of nutritious crops to ensure quality control and to deliver the right products to consumers (Tripoli and Schmidhuber 2018).

\section{Next-Generation Multi-Nutrient Rice Varieties}

Breeding for rice varieties with multiple beneficial minerals and vitamins is essential to develop them holistically for one biofortified rice product. Efforts to develop rice varieties with high $\mathrm{Zn}$, high $\mathrm{Fe}$, selenium, vitamin $\mathrm{A}$, proteins, amino acids, etc., should be given a priority. It will also be interesting to combine high nutrient content with traits beneficial to health, such as low glycemic index, antioxidants, and resistance starch. Also, there is a need to diminish the amount of harmful elements such as arsenic and cadmium. The increase in demand for rice varieties with improved grain quality and nutrition means that a suite of rice varieties with different combinations of traits targeted to different regions should be developed. 


\section{Conclusions}

Biofortification of rice with improved $\mathrm{Zn}$ content is an efficient means to tackle $\mathrm{Zn}$ malnutrition in predominantly rice-consuming developing countries. Some success has been achieved in understanding the molecular basis of $\mathrm{Zn}$ accumulation and the effects of $\mathrm{G} \times \mathrm{E}$, and finally in developing and releasing $\mathrm{Zn}$-biofortified rice varieties for the target countries. In all, ten high- $\mathrm{Zn}$ rice varieties have been released in four Asian countries. Efforts have begun to mainstream grain $\mathrm{Zn}$ to ensure that the $\mathrm{Zn}$ trait becomes an integral part of future varieties. Huge scope exists to apply advanced genomics technologies such as genomic selection and genome editing to speed up high-Zn varietal development. An efficient rice value chain for Zn-biofortified varieties, quality control, and promotion are essential for successful adoption and consumption. The development of next-generation high-Zn rice varieties with higher grain-Zn content, stacking of multiple nutrients, along with good grain quality and acceptable agronomic traits has to be fast-tracked. Healthier rice has a large demand from all stakeholders, so we need to keep up the pace of developing nutritious rice to meet the demand and to achieve nutritional security.

\section{References}

Alqabbani H, AlBadr N (2020) Zinc status (intake and level) of healthy elderly individuals in Riyadh and its relationship to physical health and cognitive impairment. Clin Nutr Exp 29:10-17. https://doi.org/10.1016/j.yclnex.2019.12.001

Anandan A, Rajiv G, Eswaran R, Prakash M (2011) Genotypic variation and relationships between quality traits and trace elements in traditional and improved rice (Oryza sativa L.) genotypes. J Food Sci 76(4):122-130

Andreini C, Bertini I, Rosato A (2009) Metalloproteomes: a bioinformatic approach. Acc Chem Res 42:1471-1479

Anuradha K, Agarwal S, Batchu AK, Babu AP, Swamy BPM, Longva T, Sarla N (2012) Evaluating rice germplasm for iron and zinc concentration in brown rice and seed dimensions. J Geophys Res 4:19-25

Arbelaez JD, Dwiyanti MS, Tandayu E et al (2019) 1k-RiCA (1K-Rice Custom Amplicon) a novel genotyping amplicon-based SNP assay for genetics and breeding applications in rice. Rice 12:55. https://doi.org/10.1186/s12284-019-0311-0

Arcade A, Labourdette A, Falque M, Mangin B, Chardon F, Charcosset A, Joets J (2004) BioMercator: integrating genetic maps and QTL towards discovery of candidate genes. Bioinformatics 20(14):2324-2326

Balakrishnan D, Surapaneni M, Yadavalli VR, Addanki KR, Mesapogu S, Beerelli K, Neelamraju S (2020) Detecting CSSLs and yield QTLs with additive, epistatic and QTL $\times$ environment interaction effects from Oryza sativa $\times$ O. nivara IRGC81832 cross. Sci Rep 10(1):1-18. https://doi.org/10.1038/s41598-020-64300-0

Bandillo N, Raghava C, Muyco PA, Sevilla MAL, Lobina IT, Dilla-Ermita CJ, Tung CW, McCouch S, Thomson M, Mauleon R, Singh RK, Gregorio G, Redoña E, Leung H (2013) Multi-parent advanced generation inter-cross (MAGIC) populations in rice: progress and potential for genetics research and breeding. Rice 6:11

Banerjee S, Sharma DJ, Verulkar SB, Chandel G (2010) Use of in silico and semi quantitative RT-PCR approaches to develop nutrient rich rice (Oryza sativa L). Indian J Biotechnol 9:203-212 
Bashir K, Inoue H, Nagasaka S, Takahashi M, Nakanishi H, Mori S, Nishizawa NK (2006) Cloning and characterization of deoxymugineic acid synthase genes from graminaceous plants. J Biol Chem 281:32395-32402

Ben-Ari G, Lavi U (2012) Marker assisted selection in plant breeding. In: Plant biotechnology and agriculture. Academic Press, Cambridge, pp 163-184

Bernardo R (2008) Molecular markers and selection for complex traits in plants: learning from the last 20 years. Crop Sci 48:1649

Black RE, Allen LH, Bhutta ZA, Caulfield LE, de Onis M, Ezzati M, Mathers C, Rivera J (2008) Maternal and child undernutrition: global and regional exposures and health consequences. Lancet 371:243-260

Bouis H (2017) An overview of the landscape and approach for biofortification in Africa. Afr J Food Agric Nutr Dev 17(2):11848-11864. https://doi.org/10.18697/ajfand.78.harvestplus01

Bouis H, Saltzman A (2017) Improving nutrition through biofortification: a review of evidence from HarvestPlus, 2003 through 2016. Glob Food Secur 12:49-58. https://doi.org/10.1016/j. gfs.2017.01.009

Boyle EA, Li YI, Pritchard JK (2017) An expanded view of complex traits: from polygenic to omnigenic. Cell 169:1177-1186. https://doi.org/10.1016/j.cell.2017.05.038

Brar B, Jain S, Singh R, Jain RK (2011) Genetic diversity for iron and zinc contents in a collection of 220 rice (Oryza sativa L.) genotypes. Indian J Genet Plant Breed 71(1):67-73

Broadley MR, White PJ, Hammond JP, Zelko I, Lux A (2007) Zinc in plants. New Phytol 173:677-702

Brooks WA, Yunus M, Santosham M et al (2004) Zinc for severe pneumonia in very young children: double-blind placebo-controlled trial. Lancet 363:1683-1688

Brown KH, Peerson JM, Kimmons JE, Hotz C (2002) Options for achieving adequate intake from home-prepared complementary foods in low income countries. In: Black RE, Fliescher Michaelson K (eds) Public health issues in infant and child nutrition. Nestle nutrition workshop series. Pediatric program, vol 48. Lippincott Williams and Wilkins; Nestec Ltd, Philadelphia, PA; Vevey, pp 239-256

Cakmak I (2000) Role of zinc in protecting plant cells from reactive oxygen species. New Phytol 146:185-205

Calayugan MIC, Formantes AK, Amparado A, Descalsota-Empleo GI, Nha CT, Inabangan-Asilo MA et al (2020) Genetic analysis of agronomic traits and grain iron and zinc concentrations in a doubled haploid population of rice (Oryza sativa L.). Sci Rep 10(1):2283. https://doi. org/10.1038/s41598-020-59184-z

Caulfield LE, Richard SA, Rivera JA et al (2006) Stunting, wasting, and micronutrient deficiency disorders. In: Jamison DT, Breman JG, Measham AR et al (eds) Disease control priorities in developing countries, 2nd edn. The International Bank for Reconstruction and Development/ The World Bank, Washington, DC. Chapter 28. https://www.ncbi.nlm.nih.gov/books/ NBK11761/. Co-published by Oxford University Press, New York

CGIAR (2018) 3-year system business plan companion document. CGIAR five-year biofortification strategy 2019-2023. CGIAR, Montpellier

Chandel G, Banerjee S, See S, Meena R, Sharma DJ, Verulkar SB (2010) Effects of different nitrogen fertilizer levels and native soil properties on rice grain $\mathrm{Fe}, \mathrm{Zn}$ and protein contents. Rice Sci 17:213-227

Chasapis C, Ntoupa P, Spiliopoulou C, Stefanidou M (2020) Recent aspects of the effects of zinc on human health. Arch Toxicol 94(5):1443-1460. https://doi.org/10.1007/s00204-020-02702-9

Chen K, Gao C (2013) Targeted genome modification technologies and their applications in crop improvements. Plant Cell Rep 33:575-583

Cheng ZQ, Huang XQ, Zhang YZ, Qian J (2005) Diversity in the content of some nutritional components in husked seeds of three wild rice species and rice varieties in Yunnan Province of China. J Integr Plant Biol 147:1260-1270

Christian M, Cermak T, Doyle EL, Schmidt C, Zhang F, Hummel A et al (2010) Targeting DNA double-strand breaks with TAL effector nucleases. Genetics 186:757-761 
Cobb JN, Juma RU, Biswas PS, Arbalaez JD, Rutkoski J, Atlin G, Hagen T, Quinn M, Ng EH (2019) Enhancing the rate of genetic gain in public-sector plant breeding programs: lessons from the breeder's equation. Theor Appl Genet 132:627. https://doi.org/10.1007/s00122-019-03317-0

Collard BC, Mackill DJ (2008) Marker-assisted selection: an approach for precision plant breeding in the twenty-first century. Philos Trans R Soc Lond Ser B Biol Sci 363:557-572

Collard BCY, Beredo JC, Lenaerts B, Mendoza R, Santelice R, Lopena V, Verdeprado H, Raghavan C, Gregorio GB, Vial L, Demomt M, Biswas PS, Iftkhauddaula KM, Rahman MA, Cobb JN, Islam MA (2017) Revisiting rice breeding methods: evaluating the use of rapid generation advance (RGA) for routine rice breeding. Plant Prod Sci 20:1. https://doi.org/10.108 0/1343943X.2017.1391705

Descalsota GIL, Swamy BPM, Zaw H, Inabangan-Asilo MA, Amparado A, Mauleon R et al (2018) Genome-wide association mapping in a rice MAGIC Plus population detects QTLs and genes useful for biofortification. Front Plant Sci 9:1-20. https://doi.org/10.3389/fpls.2018.01347

Descalsota-Empleo GI, Noraziyah AAS, Navea IP, Chung C, Dwiyanti MS, Labios RJD, Ikmal AM, Juanillas VM, Inabangan-Asilo MA, Amparado A, Reinke R, Vera Cruz CM, Chin JH, Swamy BPM (2019a) Genetic dissection of grain nutritional traits and leaf blight resistance in rice. Genes 10:30. https://doi.org/10.3390/genes 10010030

Descalsota-Empleo GI, Amparado A, Inabangan-Asilo MA, Tesoro F, Stangoulis J, Reinke R, Swamy BPM (2019b) Genetic mapping of QTL for agronomic traits and grain mineral elements in rice. Crop J 7(4):560-572. https://doi.org/10.1016/j.cj.2019.03.002

Dixit S, Singh UM, Abbai R, Ram T, Singh VK, Paul A, Virk PS, Kumar A (2019) Identification of genomic region(s) responsible for high iron and zinc content in rice. Sci Rep 9:8136. https:// doi.org/10.1038/s41598-019-43888-y

FAO (Food and Agriculture Organization of the United Nations) (2014) Country nutrition paper Bangladesh. In: International Conference on Nutrition, 19-21 November 2014. FAO, Rome

FAO (Food and Agriculture Organization of the United Nations) (2016) Statistical database. FAO, Rome. http://faostat3.fao.org/home/E

Gande NK, Rakhi S, Kundur PJ, Amabti R, Bekele BD, Shashidhar HE (2013) Evaluation of recombinant inbred lines of rice (Oryza sativa L.) for grain zinc content, yield related traits and identification of transgressant lines grown under aerobic conditions. Asian J Exp Biol Sci 4(4):567-574

Gangashetty PI, Salimath PM, Hanamaratt NG (2013) Genetic variability studies in genetically diverse non-basmati local aromatic genotypes of rice (Oryza sativa L.). Rice Genom Genet 4:4-8

Gao C (2015) Genome editing in crops: from bench to field. Natl Sci Rev 2:13-15

Garcia-Oliveira AL, Tan L, Fu Y, Sun C (2009) Genetic identification of quantitative trait loci for contents of mineral nutrients in rice grain. J Integr Plant Biol 51:84-92

Garcia-Oliveira AL, Chander S, Ortiz R, Menkir A, Gedil M (2018) Genetic basis and breeding perspectives of grain iron and zinc enrichment in cereals. Front Plant Sci 9:1-13. https://doi. org/10.3389/fpls.2018.00937

Garg M, Sharma N, Sharma S, Kapoor P, Kumar A, Chunduri V, Arora P (2018) Biofortified crops generated by breeding, agronomy, and transgenic approaches are improving lives of millions of people around the world. Front Nutr 5:12. https://doi.org/10.3389/fnut.2018.00012

Gödecke T, Stein AJ, Qaim M (2018) The global burden of chronic and hidden hunger: trends and determinants. Glob Food Secur 17:21-29. https://doi.org/10.1016/j.gfs.2018.03.004

Goffinet B, Gerber S (2000) Quantitative trait loci: a meta-analysis. Genetics 155(1):463-473

Gregorio GB (2002) Progress in breeding for trace minerals in staple crops. J Nutr 132:500-502

Gregorio GB, Senadhira D, Htut T, Graham RD (2000) Breeding for trace mineral density in rice. Food Nutr Bull 21:382-386

Gross BL, Zhao Z (2014) Archaeological and genetic insights into the origins of domesticated rice. Proc Natl Acad Sci U S A 111(17):6190

Guild GE, Paltridge NG, Andersson MS, Stangoulis JCR (2017) An energy-dispersive X-ray fluorescence method for analysing $\mathrm{Fe}$ and $\mathrm{Zn}$ in common bean, maize and cowpea biofortification programs. Plant Soil 419(1-2):457-466. https://doi.org/10.1007/s11104-017-3352-4 
Guo G, Zhao F, Wang Y, Zhang Y, Du L, Su G (2014) Comparison of single-trait and multiple-trait genomic prediction models. BMC Genet 15:30-36

Guo R, Dhliwayo T, Mageto EK, Palacios-Rojas N, Lee M, Yu D, Ruan Y, Zhang A, San Vicente F, Olsen M, Crossa J, Prasanna BM, Zhang L, Zhang X (2020) Genomic prediction of kernel zinc concentration in multiple maize populations using genotyping-by-sequencing and repeat amplification sequencing markers. Front Plant Sci 11:1-15. https://doi.org/10.3389/ fpls.2020.00534

Hanieh S, High H, Boulton J (2020) Nutrition justice: uncovering invisible pathways to malnutrition. Front Endocrinol 11:150. https://doi.org/10.3389/fendo.2020.00150

HarvestPlus (2012) International Rice Research Institute. http://www.harvestplus.org/content/ zinc-rice-india

HarvestPlus (2020). https://www.harvestplus.org/knowledge-market/BPI. Accessed 20 Jun 2020

Hayashi T, Iwata H (2013) A Bayesian method and its variational approximation for prediction of genomic breeding values in multiple traits. BMC Bioinformatics 14:34

Hill WG, Michael E, Goddard ME, Visscher PM (2008) Data and theory point to mainly additive genetic variance for complex traits. PLoS Genet 4:e1000008. https://doi.org/10.1371/journal. pgen. 1000008

Hotz C, McClafferty B (2007) From harvest to health: challenges for developing biofortified staple foods and determining their impact on micronutrient status. Food Nutr Bull 28(2):271-279

Impa SM, Morete MJ, Ismail AM, Schulin R, Johnson-Beebout SE (2013) Zn uptake translocation and grain $\mathrm{Zn}$ loading in rice (Oryza sativa $\mathrm{L}$ ) genotypes selected for $\mathrm{Zn}$-deficiency tolerance and high grain Zn. J Exp Bot 64:2739-2751

Inabangan-Asilo MA, Mallikarjuna Swamy BP, Amparado AF, Descalsota-Empleo GIL, Arocena EC, Reinke R (2019) Stability and G $\times$ E analysis of zinc-biofortified rice genotypes evaluated in diverse environments. Euphytica 215(3):1-17. https://doi.org/10.1007/s10681-019-2384-7

Inoue H, Higuchi K, Takahashi M, Nakanishi H, Mori S, Nishizawa NK (2003) Three rice nicotianamine synthase genes, OsNAS1, OsNAS2, and OsNAS3 are expressed in cells involved in long-distance transport of iron and differentially regulated by iron. Plant J 36:366-381

Inoue H, Takahashi M, Kobayashi T, Suzuki M, Nakanishi H, Mori S, Nishizawa NK (2008) Identification and localisation of the rice nicotianamine aminotransferase gene OsNAAT1 expression suggests the site of phytosiderophore synthesis in rice. Plant Mol Biol 66:193-203

IOM (Institute of Medicine) (2001) Dietary reference intakes for vitamin A, vitamin K, arsenic, boron, chromium, copper, iodine, iron, manganese, molybdenum, nickel, silicon, vanadium, and zinc. National Academy Press, Washington, DC

Iqbal S, Ali I, Rust P, Kundi M, Ekmekcioglu C (2020) Selenium, zinc, and manganese status in pregnant women and its relation to maternal and child complications. Nutrients 12(3):725. https://doi.org/10.3390/nu12030725

Ishikawa R, Iwata M, Taniko K, Monden G, Miyazaki N, Orn C et al (2017) Detection of quantitative trait loci controlling grain zinc concentration using Australian wild rice, Oryza meridionalis, a potential genetic resource for biofortification of rice. PLoS One 12(10):e0187224. https:// doi.org/10.1371/journal.pone.0187224

Ishimaru Y, Suzuki M, Kobayashi T, Takahashi M, Nakanishi H, Mori S, Nishizawa NK (2005) OsZIP4, a novel zinc-regulated zinc transporter in rice. J Exp Bot 56:3207-3214

IZiNCG (International Zinc Nutrition Consultative Group) (2009) Systematic reviews of zinc intervention strategies. Food Nutr Bull 25:S12-S40

Jeong O-Y, Lee J-H, Jeong E-G et al (2020) Analysis of QTL responsible for grain iron and zinc content in doubled haploid lines of rice (Oryza sativa) derived from an intra-japonica cross. Plant Breed 139:344-355. https://doi.org/10.1111/pbr.12787

Jia Y, Jannink JL (2012) Multiple-trait genomic selection methods increase genetic value prediction accuracy. Genetics 192:1513-1522

Jin T, Chen J, Zhu L, Zhao Y, Guo J, Huang Y (2015) Comparative mapping combined with homology-based cloning of the rice genome reveals candidate genes for grain zinc and iron concentration in maize. BMC Genet 16(1):17

Jinek M, Chylinski K, Fonfara I, Hauer M, Doudna JA, Charpentier E (2012) A programmable dual-RNA-guided DNA endonuclease in adaptive bacterial immunity. Science 337:816-821 
Johnson AAT, Kyriacou B, Callahan DL, Carruthers L, Stangoulis J (2011) Constitutive overexpression of the $O s N A S$ gene family reveals single-gene strategies for effective iron- and zincbiofortification of rice endosperm. PLoS One 6:e24476

Joshi AK, Crossa J, Arun B, Chand R, Trethowan R, Vargas M, Monasterio IO (2010) Genotype $x$ environment interaction for zinc and iron concentration of wheat grain in eastern Gangetic plains of India. Field Crops Res 116:268. https://doi.org/10.1016/j.fcr.2010.01.004

Kakei Y, Ishimaru Y, Kobayashi T, Yamakawa T, Nakanshi H, Nishizawa NK (2012) OsYSL16 plays a role in the allocation of iron. Plant Mol Biol 79:583-594

Kim YG, Cha J, Chandrasegaran S (1996) Hybrid restriction enzymes: zinc finger fusions to Fok I cleavage domain. Proc Natl Acad Sci U S A 93:1156-1160

Lado B, Vázquez D, Quincke M, Silva P, Aguilar I, Gutiérrez L (2018) Resource allocation optimization with multi-trait genomic prediction for bread wheat (Triticum aestivum L.) baking quality. Theor Appl Genet 131:2719. https://doi.org/10.1007/s00122-018-3186-3

Lan HX, Wang ZF, Wang QH, Wang MM, Bao YM, Huang J, Zhang HS (2013) Characterization of a vacuolar zinc transporter OZT1 in rice (Oryza sativa L.). Mol Biol Rep 40(2):1201-1210

Lee S, Jeong HJ, Kim SA, Lee J, Guerinot ML, An G (2010a) OsZIP5 is a plasma membrane zinc transporter in rice. Plant Mol Biol 73(4-5):507-517

Lee S, Kim SA, Lee J, Guerinot ML, An G (2010b) Zinc deficiency-inducible OsZIP8 encodes a plasma membrane-localized zinc transporter in rice. Mol Cell 29(6):551-558

Lee S-M, Kang J-W, Lee J-Y, Seo J, Shin D, Cho J-H, Jo S, Song Y-C, Park D-S, Ko J-M, Koh H-J, Lee J-H (2020) QTL analysis for Fe and Zn concentrations in rice grains using a doubled haploid population derived from a cross between rice (Oryza sativa) cultivar 93-11 and milyang 352. Plant Breed Biotech 8(1):69-76

Li J, Wang J, Zeigler RS (2014) The 3,000 rice genomes project: new opportunities and challenges for future rice research. Giga Sci 3:8

de los Campos G, Naya H, Gianola D, Crossa J, Legarra A, Manfredi E, Weigel K, Cotes JM (2009) Predicting quantitative traits with regression models for dense molecular markers and pedigree. Genetics 182(1):375-385

Ma G, Jin Y, Li Y, Zhai F, Kok FJ, Jacobsen E, Yang X (2008) Iron and zinc deficiencies in China: what is a feasible and cost-effective strategy? Public Health Nutr 11:632-638

Maret W (2017) Zinc in cellular regulation: the nature and significance of "zinc signals". Int J Mol Sci 18:2285

Maret W, Li Y (2009) Coordination dynamics of zinc in proteins. Chem Rev 109:4682-4707

Martínez CP, Borrero J, Taboada R, Viana JL, Neves P, Narvaez L, Puldon V, Adames A, Vargas A (2010) Rice cultivars with enhanced iron and zinc content to improve human nutrition. In: 28th International Rice Research Conference, Hanoi, Vietnam, 8-12 November 2010. OP10: Quality Grain, Health, and Nutrition

McDonald GK, Genc Y, Graham RD (2008) A simple method to evaluate genetic variation in grain zinc concentration by correcting for differences in grain yield. Plant Soil 306:49. https://doi. org/10.1007/s11104-008-9555-y

Meuwissen THE, Hayes BJ, Goddard ME (2001) Prediction of total genetic value using genomewide dense marker maps. Genetics 157:1819-1829

Milovanovic V, Smutka L (2017) Asian countries in the global rice market. Acta Univ Agric Silvicult Mendel Brunensis 65(2):679-688. https://doi.org/10.11118/actaun201765020679

Montesinos-Lopez OA, Montesinos-Lopez A, Crossa J, Toledo FH, Perez-Hernandez O, Eskridge KM et al (2016) A genomic Bayesian multi-trait and multi-environment model. G3 6(9):2725-2744. https://doi.org/10.1534/g3.116.032359

Montesinos-López A, Montesinos-López OA, Gianola D, Crossa J, Hernández-Suárez CM (2019) Multivariate Bayesian analysis of on-farm trials with multiple-trait and multiple-environment data. Agron J 3(1):1-12. https://doi.org/10.2134/agronj2018.06.0362

Morete MJ, Impa MS, Rubianes F, Beebout SEJ (2011) Characterization of zinc uptake and transport in rice under reduced conditions in agar nutrient solution. In: 14th Philippine Society of Soil Science and Technology, Scientific Conference, 25-27 May 2011. Visayas State University, Baybay 
Naik SM, Raman AK, Nagamallika M, Venkateshwarlu C, Singh SP, Kumar S, Singh SK, Ahmed HU, Das SP, Prasad K, Izhar T, Mandal NP, Singh NK, Yadav S, Reinke R, Swamy BPM, Virk P, Kumar A (2020) Genotype $\times$ environment interactions for grain iron and zinc content in rice. J Sci Food Agric 100:4150. https://doi.org/10.1002/jsfa.10454

Nha CT (2019) Dissection of QTL and genes for agronomic and biofortification traits in six connected populations of rice. Dissertation. University of the Philippines, Los Baños. $224 \mathrm{p}$

Norton GJ, Deacon CM, Xiong L, Huang S, Meharg AA, Price AH (2010) Genetic mapping of the rice ionome in leaves and grain: identification of QTLs for 17 elements including arsenic, cadmium, iron and selenium. Plant Soil 329:139-153

Norton GJ, Douglas A, Lahner B, Yakubova E, Guerinot ML et al (2014) Genome wide association mapping of grain arsenic, copper, molybdenum and zinc in rice (Oryza sativa L.) grown at four international field sites. PLoS One 9(2):e89685. https://doi.org/10.1371/journal.pone.0089685

Nozoye T, Nagasaka S, Kobayashi T, Takahashi M, Sato Y, Sato Y, Uozumi N, Nakanishi H, Nishizawa NK (2011) Phytosiderophore efflux transporters are crucial for iron acquisition in graminaceous plants. J Biol Chem 286:5446-5454

Palanog AD, Calayugan MIC, Descalsota-Empleo GI et al (2019) Zinc and iron nutrition status in the Philippines population and local soils. Front Nutr 6:81

Pandian SS, Robin S, Vinod KK, Rajeswari S, Manonmani S, Subramanian KS, Saraswathi R, Kirubhakaran APM (2011) Influence of intrinsic soil factors on genotype-by-environment interactions governing micronutrient content of milled rice grains. AJCS 5(13):1737-1744

Peng S, Laza RC, Visperas RM, Sanico AL, Cassman KG, Khush GS (2000) Grain yield of rice cultivars and lines developed in the Philippines since 1966. Crop Sci 40:307-314

Peng S, Huang J, Sheehy JE, Laza RC, Visperas RM, Zhong XH et al (2004) Rice yields decline with higher night temperature from global warming. Proc Natl Acad Sci U S A 101(27):9971-9975

Prasad R, Shivay YS, Kumar D (2014) Agronomic biofortification of cereal grains with iron and zinc. Adv Agron 125:55-91. https://doi.org/10.1016/B978-0-12-800137-0.00002-9

Ramesh SA, Shin R, Eide DJ, Schachtman P (2003) Differential metal selectivity and gene expression of two zinc transporters from rice. Plant Physiol 133:126-134

Rampa F, Lammers E, Linnemann A, Schoustra S, de Winter D (2020) African indigenous foods: opportunities for improved food and nutrition security. Food \& Business Knowledge Platform. https://knowledge4food.net/african-indigenous-foods/

Rana MK, Bhat KV (2004) A comparison of AFLP and RAPD markers for genetic diversity and cultivar identification in cotton. J Plant Biochem Biotechnol 13:19-24

Raza Q, Riaz A, Sabar M, Atif RM, Bashir K (2019) Meta-analysis of grain iron and zinc associated QTLs identified hotspot chromosomal regions and positional candidate genes for breeding biofortified rice. Plant Sci 288:110214. https://doi.org/10.1016/j.plantsci.2019.110214

Ritchie H, Reay D, Higgins P (2018) Quantifying, projecting, and addressing India's hidden hunger. Front Sustain Food Syst 2:11. https://doi.org/10.3389/fsufs.2018.00011

Sasaki A, Yamaji N, Xia J, Ma JF (2011) OsYSL6 is involved in the detoxification of excess manganese in rice. Plant Physiol 157:1832-1840

Sathisha TN (2013) Genetic variation among traditional landraces of rice with specific reference to nutrition al quality. Karnataka J Agric Sci 26:474

Sazawal S, Black RE, Ramsan M, Chwaya HM, Dutta A, Dhingra U, Stoltzfus RJ, Othman MK, Kabole FM (2007) Effect of zinc supplementation on mortality in children aged 1-48 months: a community-based randomised placebo-controlled trial. Lancet 369(9565):927-934

Schulthess AW, Yu W, Miedaner T, Wilde P, Reif JC, Zhao Y (2016) Multiple-trait and selection indices genomic predictions for grain yield and protein content in rye for feeding purposes. Theor Appl Genet 129:273-287

Shamshad M, Sharma A (2018) The usage of genomic selection strategy in plant breeding. In: Next generation plant breeding. InTech, Rijeka. https://doi.org/10.5772/intechopen.76247

Siwela M, Pillay K, Govender L, Lottering S (2020) Biofortified crops for combating hidden hunger in South Africa: availability, acceptability, micronutrient retention and bioavailability. Foods 9(6):815. https://doi.org/10.3390/foods9060815

Soe YP (2020) Meta-analysis of quantitative trait loci associated with grain zinc content in rice. Dissertation. University of the Philippines, Los Baños. $180 \mathrm{pp}$ 
Spindel J, Begum H, Akdemir D, Virk P, Collard B, Redoña E et al (2015) Genomic selection and association mapping in rice (Oryza sativa): effect of trait genetic architecture, training population composition, marker number and statistical model on accuracy of rice genomic selection in elite, tropical rice breeding lines. PLoS Genet 11(2):e1004982. https://doi.org/10.1371/journal. pgen. 1004982

Swamy BM, Vikram P, Dixit S, Ahmed HU, Kumar A (2011) Meta-analysis of grain yield QTL identified during agricultural drought in grasses showed consensus. BMC Genomics 12:319. https://doi.org/10.1186/1471-2164-12-319

Swamy BPM, Rahman MA, Inabangan-Asilo MA, Amprado A, Manito C, Chada-Mohanty P, Reinike R, Slamet-Loedin IH (2016) Advances in breeding for high grain Zinc in rice. Rice 9:49. https://doi.org/10.1186/s12284-016-0122-5

Swamy BPM, Kaladhar K, Anuradha K, Batchu AK, Longvah T, Sarla N (2018a) QTL analysis for grain iron and zinc concentrations in two $O$. nivara derived backcross populations. Rice Sci 25(4):197-207. https://doi.org/10.1016/j.rsci.2018.06.003

Swamy BPM, Descalsota GIL, Nha CT, Amparado A, Inabangan-Asilo MA, Manito C, Tesoro F, Reinke R (2018b) Identification of genomic regions associated with agronomic and biofortification traits in DH populations of rice. PLoS One 13(8):1-20. https://doi.org/10.1371/journal. pone.0201756

Szymlek-Gay EA, Ferguson EL, Heath AL, Gray AR, Gibson RS (2009) Food-based strategies improve iron status in toddlers: a randomized controlled trial. Am J Clin Nutr 90:1541-1551

Tielsch JM, Khatry SK, Stoltzfus RJ et al (2007) Effect of daily zinc supplementation on child mortality in southern Nepal: a community-based, cluster randomized, placebo-controlled trail. Lancet 370:1230-1239

Torheim LE, Ferguson EL, Penrose K, Arimond M (2010) Women in resource-poor settings are at risk of inadequate intakes of multiple micronutrients. J Nutr 140:2051S-2058S

Trijatmiko KR, Dueñas C, Tsakirpaloglou N, Torrizo L, Arines FM, Adeva C, Balindong J, Oliva N, Sapasap MV, Borrero J, Rey J, Francisco P, Nelson A, Nakanishi H, Lombi E, Tako E, Glahn RP, Stangoulis J, Chadha-Mohanty P, Johnson AAT, Tohme J, Barry G, Slamet-Loedin $\mathrm{IH}$ (2016) Biofortified indica rice attains iron and zinc nutrition dietary targets in the field. Sci Rep 6:19792. https://doi.org/10.1038/srep19792

Tripoli M, Schmidhuber J (2018) Emerging opportunities for the application of blockchain in the agri-food industry. FAO, ICTSD, Rome, Geneva. Licence: CC BY-NC-SA 3.0 IGO

Tsakirpaloglou N, Mallikarjuna Swamy BP, Acuin C, Slamet-Loedin IH (2019) Biofortified Zn and Fe rice: potential contribution for dietary mineral and human health. In: Jaiwal P, Chhillar A, Chaudhary D, Jaiwal R (eds) Nutritional quality improvement in plants. Concepts and strategies in plant sciences. Springer, Cham

UNICEF (2013) Improving child nutrition: the achievable imperative for global progress. United Nations Children's Fund, United Nations Organization, New York, NY

Wang Y, Wei Y, Dong L, Lu L, Feng Y, Zhang J et al (2014) Improved yield and Zn accumulation for rice grain by $\mathrm{Zn}$ fertilization and optimized water management. J Zhejiang Univ Sci B 15(4):365-374. https://doi.org/10.1631/jzus.b1300263

Wassmann R, Jagadish SVK, Sumfleth K, Pathak H, Howell G, Ismail A et al (2009) Regional vulnerability of climate change impacts on Asian rice production and scope for adaptation. Adv Agron 102:91-133

Welch RM, Graham RD (2004) Breeding for micronutrients in staple food crops from a human nutrition perspective. J Exp Bot 55:353-364

White PJ, Broadley MR (2009) Biofortification of crops with seven mineral elements often lacking in human diets - iron, zinc, copper, calcium, magnesium, selenium and iodine. Review. New Phytol 182:49-84. https://doi.org/10.1111/j.1469-8137.2008.02738.x

WHO (World Health Organization) (1998) Complementary feeding of young children in developing countries: a review of current scientific knowledge. WHO, Geneva

WHO (World Health Organization) (2003) Joint WHO/FAO Expert Consultation on diet, nutrition and the prevention of chronic diseases. WHO, Geneva

Widodo B, Broadley MR, Rose T, Frei M, Pariasca-Tanaka J, Yoshihashi T, Thomson M, Hammond JP, Aprile A, Close TJ, Ismail AM, Wissuwa MM (2010) Response to zinc deficiency of two 
rice lines with contrasting tolerance is determined by root growth maintenance and organic acid exudation rates, and not by zinc-transporter activity. New Phytol 186:400-414

Wissuwa M, Ismail AM, Graham RD (2008) Rice grain zinc concentrations as affected by genotype, native soil-zinc availability, and zinc fertilization. Plant Soil 306:37. https://doi. org/10.1007/s11104-007-9368-4

Young G, Mortimer E, Gopalsamy G, Alpers D, Binder H, Manary M et al (2014) Zinc deficiency in children with environmental enteropathy-development of new strategies: report from an expert workshop. Am J Clin Nutr 100(4):1198-1207. https://doi.org/10.3945/ajcn.113.075036

Zarcinas BA, Cartwright B, Spouncer LR (1987) Nitric acid digestion and multi element analysis of plant material by inductively coupled plasma spectrometry. Commun Soil Sci Plant Anal 18:131-146

Zaw H, Raghavan C, Pocsedio A, Swamy BPM, Jubay ML, Singh RK et al (2019) Exploring genetic architecture of grain yield and quality traits in a 16-way indica by japonica rice MAGIC global population. Sci Rep 9(1):1-11. https://doi.org/10.1038/s41598-019-55357-7

Zhang Y, Xu Y, Yi H, Gong J (2012) Vacuolar membrane transporters OsVIT1 and OsVIT2 modulate iron translocation between flag leaves and seeds in rice. Plant J 72:400-410

Open Access This chapter is licensed under the terms of the Creative Commons Attribution 4.0 International License (http://creativecommons.org/licenses/by/4.0/), which permits use, sharing, adaptation, distribution and reproduction in any medium or format, as long as you give appropriate credit to the original author(s) and the source, provide a link to the Creative Commons license and indicate if changes were made.

The images or other third party material in this chapter are included in the chapter's Creative Commons license, unless indicated otherwise in a credit line to the material. If material is not included in the chapter's Creative Commons license and your intended use is not permitted by statutory regulation or exceeds the permitted use, you will need to obtain permission directly from the copyright holder.

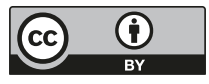

